\title{
Geological context of the Boumnyebel talcschists (Cameroun): Inferences on the Pan-African Belt of Central Africa
}

\section{Le contexte géologique des talcschistes de Boumnyebel (Cameroun) : implications pour la chaîne panafricaine d'Afrique centrale}

\author{
Clément Yonta-Ngoune $^{\underline{a}, \underline{b}}$, Charles Nkoumbou $^{\underline{b}, \underline{c}}$, Pierre Barbey $^{\mathrm{a}}{ }^{\mathrm{a}}$, Nicole Le Breton ${ }^{\mathrm{d}}$, \\ Jean-Marc Montel $^{\mathrm{e}}$ and Frédéric Villieras ${ }^{\mathrm{c}}$ \\ ${ }^{a}$ CRPG, Nancy-université, CNRS, BP 20, 54501 Vandœuvre-lès-Nancy, France \\ ${ }^{\mathrm{b}}$ LGEE, département des sciences de la terre, faculté des sciences, université de Yaoundé I, \\ BP 812, Yaoundé, Cameroun \\ ${ }^{c}$ LEM, Nancy-université, CNRS, BP 40, 54501 Vandœuvre-lès-Nancy, France \\ d Université d'Orléans, CNRS/INSU, université François-Rabelais-Tours, ISTO UMR-6113, \\ 1A, rue de la Férollerie, 45071 Orléans cedex 2, France
}

${ }^{e}$ G2R, Nancy-université, CNRS, BP 70 239, 54506 Vandœuvre-lès-Nancy, France

\begin{abstract}
The talcschists of the Boumnyebel area (southern Cameroon) form $\leq 30 \mathrm{~m}$ thick discontinuous layers within a Pan-African nappe unit (Yaoundé group), which includes, at the base, muscovite + biotite \pm garnet micaschists associated with amphibolites and pyroxenites, and, at the top, muscovite + biotite + garnet + kyanite micaschists locally associated with marble and amphibolites. The metamorphic peak $\left(\sim 650^{\circ} \mathrm{C} / 9.5 \mathrm{kbar}\right.$; ca. $\left.620 \mathrm{Ma}\right)$ postdates nappe emplacement. Isograds are in normal position, micaschists passing downwards to migmatites in the northwestern part of the area studied. The rock types in the lower part of this nappe suggest active margin environments with detrital input from a nearby continental crust (arc or back-arc context).
\end{abstract}

\section{Résumé}

Les talcschistes de la région de Boumnyebel (Sud Cameroun) forment des niveaux discontinus ( $\leq 30 \mathrm{~m}$ ) dans une nappe panafricaine (groupe de Yaoundé), constituée, à la base, de micaschistes à muscovite + biotite \pm grenat associés à des amphibolites et pyroxénites et vers le haut de micaschistes à muscovite + biotite + grenat + disthène localement associés à des marbres et amphibolites. Le pic métamorphique $\left(\sim 650{ }^{\circ} \mathrm{C} / \sim 9,5 \mathrm{kbar}\right.$; vers $\left.620 \mathrm{Ma}\right)$ est postérieur à la mise en place des nappes. Les isogrades sont en position normale, les schistes passant vers le bas à des migmatites au Nord-Ouest de la région étudiée. La nature des faciès lithologiques de la partie inférieure de cette nappe suggère l'existence d'une marge active à proximité d'une croûte continentale (environnement d'arc ou d'arrière-arc).

Keywords: Pan-African belt; Cameroon; Yaoundé group; Talcschist; Metamorphism

Mots clés: Chaîne panafricaine; Cameroun; Groupe de Yaoundé; Talcschiste; Métamorphisme 


\section{Introduction}

The Trans-Saharan and Central African fold belts form two major Neoproterozoic orogenic structures (Fig. 1 a), which continue to the west to the Sergipano Fold Belt (Brazil), and to the east to the Oubanguides (Central African Republic and Sudan). These belts are considered to result from a collision between the São Francisco and Congo cratons to the south, the West African craton to the northwest and the Latea and Saharan metacratons to the north ([Abdelsalam et al., 2002], [Ngako et al., 2008] and [Oliveira et al., 2006]). The Central African Fold Belt (CAFB) in Cameroon has been subdivided into three geotectonic domains (Fig. 1b): The northern domain corresponds to the Poli ( Toteu et al., 2004 ), Léré ( Pouclet et al., 2006 ) and Mayo Kebbi series ( Penaye et al., 2006 ). It is interpreted as Neoproterozoic magmatic arcs (665-830 Ma) accreted against the Adamawa-Yadé domain at ca. $640 \mathrm{Ma}$, and intruded by granitoids in the $580-650 \mathrm{Ma}$ age range;

- The central Adamawa-Yadé domain is separated from the northern domain by the TcholliréBanyo fault. It consists mainly of remnants of 2.1 Ga Palaeoproterozoic crust intruded by Pan-African calc-alkaline granitoids (Toteu et al., 2004 ). Its southern limit corresponds to the Central Cameroon Shear Zone separating the Adamawa-Yadé domain from a southernmost domain (Ngako et al., 1991);

- The southernmost domain corresponds to stacked metasedimentary units (Yaoundé (

Nzenti et al., 1988 ) and Bafia ( Tchakounté et al., 2007 ) Groups) thrust onto the Congo craton (Ball et al., 1984). The Yaoundé group consists dominantly of metapelites and metagraywackes deposited in epicontinental environment and metamorphosed under highpressure conditions in the 611-616 Ma age range ([Stendal et al., 2006] and [Toteu et al., 2006]).

The tectono-metamorphic evolution and significance of the Yaounde Group is still the subject of debate. Some ([Nzenti et al., 1988] and [Penaye et al., 1993]) consider that nappe stacking is coeval with metamorphic peak conditions and anatexis, and that the Yaoundé group represents a suture zone, whereas others (Mvondo et al., 2003 H. Mvondo, S.W.J. den Brok and J. Mvondo Ondoa, Evidence of symmetric extension and exhumation of the Yaoundé nappe (Pan-African fold belt, Cameroon), J. Afr. Earth Sci. 36 (2003), pp. 215-231. Abstract | [Mvondo et al., 2003] and [Mvondo et al., 2007]) contend that the metamorphic peak is synchronous with orogen-parallel extension and that oceanic lithosphere remnants are lacking along the edge of the Congo craton.

This study deals with the westwards extension of the Yaoundé group (Boumnyebel area; [Fig. 1] and [Fig. 2]), known for the presence of mafic rocks and talcschists ([Nkoumbou et al., 2006a] and [Nkoumbou et al., 2006b]). Geological mapping and sampling were undertaken to determine the geometry of the talcschists and characterize their geological context (about 180 samples and 130 thin sections). We present new field, petrological and geochronological data, and emphasize some implications of our results on the evolution of the CAFB to the north of the Congo craton.

\section{Lithological units}

Previous works comprise the E-22 1:500,000 reconnaissance map (Champetier de Ribes and Aubague, 1956), a few U-Pb ages ([Toteu et al., 2001] and [Toteu et al., 1994]) and 
exploration works on talc and rutile occurrences ([Nkoumbou et al., 2006b] and [Stendal et al., 2006]). In agreement with these works, we distinguish:

- Palaeoproterozoic gneisses and related rocks (Nyong group) forming the relative autochthonous to the Pan-African metamorphic rocks;

- Neoproterozoic micaschists associated with mafic and ultramafic rocks (Yaoundé group).

We present here the features and distribution of the main rock types (Fig. 2). P-T conditions and age of metamorphism are given in the next section.

\subsection{The Nyong group}

It occurs in the southwestern part of the map and consists mainly of tonalitic to granitic gneisses associated with amphibolites and metasedimentary rocks recrystallized under highgrade conditions at $c a$. $2050 \mathrm{Ma}$ (Feybesse et al., 1998). It involves inherited Archaean and Palaeoproterozoic material affected by a Pan-African metamorphic imprint at $626 \pm 26 \mathrm{Ma}$ ([Lerouge et al., 2006], [Nédélec et al., 1993] and [Toteu et al., 1994]). Close to the contact with the Pan-African units (Mapan area; Fig. 2), the gneisses show NNE-SSW stretching lineation with low dip, and north-south to NW-SE striking foliation with dip to the east or northeast. These orientations are similar to those observed in the overlying Pan-African rocks, but differ from those typical of the Nyong group showing NE-SW foliation (dip to the northwest) associated with east-west to NW-SE stretching lineation (Feybesse et al., 1998). This is consistent with the reworking of the Nyong group, as shown by the base of the PanAfrican nappe, which corresponds to a tectonic melange of allochtonous Pan-African micaschist and lenses of Nyong gneiss (Feybesse et al., 1998). Phase assemblages indicate two stages of recrystallization:

- $\mathrm{qtz}+\mathrm{kfs}+\mathrm{pl}+\mathrm{bt}($ mineral abbreviations according to $(\underline{\text { Kretz, 1983 }}))$ associated with faint but widespread mylonitic structures in gneisses, and $\mathrm{hbl}+\mathrm{grtl}+\mathrm{pl}+\mathrm{qtz} \pm \mathrm{cpx} \pm \mathrm{bt}+\operatorname{mag} \pm \mathrm{ilm}$ in amphibolites;

- overgrowths of $\mathrm{ms} \pm \mathrm{bt}$ on feldspars and of ep $\pm \mathrm{ms}$ on biotite in gneisses, and development in amphibolites of euhedral grt2 overgrowths around both grt1 and mag, and of hbl coronas around cpx and mag.

\subsection{The Pan-African rocks}

From the base upwards, they consist of:

- lower bt + ms \pm grt micaschists associated with amphibolites and pyroxenites;

- talcschists and related rocks;

- upper $\mathrm{ms}+\mathrm{bt} \pm \mathrm{grt} \pm$ ky micaschists.

The overall structure corresponds to domes and basins with the main foliation $\left(\mathrm{S}_{2}\right)$ remaining close to horizontal (dip mostly $\leq 30^{\circ}$ ).

\subsubsection{Lower micaschists and related rocks}


The lower part of the Pan-African unit consists of $\mathrm{bt}+\mathrm{ms} \pm$ grt micaschists containing layers or boudins of quartzite, amphibolite and pyroxenite. At Mamb a body of metagabbro associated with pyroxenite has been dated at $618 \pm 7 \mathrm{Ma}$ (Toteu et al., 1994).

Quartzofeldspathic veins are widespread in this lower part. Micaschists show two phase assemblages:

- $\mathrm{ms}+\mathrm{bt} \pm \mathrm{chl}+\mathrm{qtz}+\mathrm{gr}+\mathrm{rt}$ included within garnet porphyroblasts and associated with a first foliation $\left(S_{1}\right)$;

- $\mathrm{ms}+\mathrm{bt}+\mathrm{grt}+\mathrm{qtz}+\mathrm{gr}+\mathrm{rt} \pm \mathrm{pl}$ outlining a second foliation $\left(\mathrm{S}_{2}\right)$.

Significant retrogression of biotite into chlorite occurs in the south close to the contact with the Nyong group. Phase assemblages in mafic rocks are:

- $\mathrm{hbl}+\mathrm{pl}+\mathrm{qtz} \pm \mathrm{grt} \pm \mathrm{bt}+\mathrm{ep}+\mathrm{spn}$ (amphibolites) associated with $\mathrm{S}_{2}$; grt is locally separated from $\mathrm{hbl}$ by a thin rim of $\mathrm{pl}$ with lower $A$ n content $\left(A n_{17-28} \mathrm{Vs} . A n_{38}\right.$ in the matrix); ep (commonly with allanite cores) occurs as inclusion in grt, or in association with the $\mathrm{S}_{2}$ assemblage, or as late euhedral crystals and symplectites with qtz;

- bt $+\mathrm{hbl}+\mathrm{pl} \pm$ grt \pm ep $+\mathrm{ilm}$ (metagabbro); large pl grains are overprinted by abundant euhedral ep needles; grt occurs as rounded centimetre-sized porphyroblasts superimposed on $\mathrm{S}_{2}$, and is commonly surrounded by a thin quartzofeldspathic rim;

- opx $+\mathrm{cpx}+\mathrm{hbl} \pm \mathrm{pl} \pm \mathrm{phl}+\mathrm{rt}$ (pyroxenites); hbl occurs as large porphyroblasts including both pyroxenes.

\subsubsection{Talcschists}

They form layers of variable thickness $(<30 \mathrm{~m})$ above the lower micaschists and amphibolites, at the 400-450 m level. Two exceptions are talcschists associated with dolomitic marble occurring in the upper micaschists at Henguégué (alt.: m500 m), and talcschists occurring in contact with the Palaeoproterozoic orthogneisses at Memel (alt.: $\approx 200 \mathrm{~m}$ ). Three phase assemblages are observed:

- almost monomineralic tlc or chl outlining $\mathrm{S}_{2}$;

- non oriented tr + tlc intergrowths and porphyroblasts of tlc (locally forming decimetre-sized rosettes), amphibole ( $\mathrm{tr} / \mathrm{rbk} / \mathrm{ath})$ or olivine;

- late retrograde assemblages consisting of chl porphyroblasts or antigorite aggregates.

Locally (e.g. Boumnyebel), decimetre-sized tremolitite enclaves arising from the complete recrystallization of talcschist occur within the micaschists just below the talcschist layers.

\subsubsection{Upper micaschists}

They are quartz-rich at the base (100-150 m) and kyanite-bearing upwards $(\leq 300 \mathrm{~m})$. The kyanite micaschists occur mainly in the northwestern part of the map as a NNE-SSW-oriented syncline (Mambé massif) and subordinately in the northeastern corner at Henguégué. Minor 
rock types consist of biotite gneisses, calc-silicate rocks and amphibolites occurring in the upper part of kyanite micaschists (Mambé), and of dolomitic marble associated with talcschist in the upper part of the quartz-rich micaschists (Henguégué). All these rocks are free of quartzofeldspathic veins. Only scarce metre-sized sills of ms + bt leucogranite, conformable to $\mathrm{S}_{2}$, occur at Henguégué. Two main phase assemblages are observed:

$\cdot \mathrm{ms}+\mathrm{bt}+\mathrm{qtz}+\mathrm{gr}+\mathrm{rt} \pm \mathrm{pl}$ included in grt and ky porphyroblasts outlining $\mathrm{S}_{1}$;

$\cdot \mathrm{ms}+\mathrm{bt}+\mathrm{grt}+\mathrm{ky}+\mathrm{qtz} \pm \mathrm{pl}+\mathrm{gr}+\mathrm{rt}$ associated with $\mathrm{S}_{2}$.

In the northwestern part of the investigated area, micaschists become migmatitic as evidenced by the near complete disappearance of muscovite and the presence of granitic leucosomes.

The micaschists range in composition from semi-pelites to aluminous shales and their protoliths have been interpreted as the erosion products of both crustal rocks and Neoproterozoic magmatic arcs (Stendal et al., 2006). Most talcschists show high Ni, Cr and Co contents ( $\geq 1000, \geq 1700, \geq 50 \mathrm{ppm}$, respectively). Their REE patterns are closely similar to those of E-MORB and diagram normalized to the primitive mantle shows negative $\mathrm{Nb}, \mathrm{Ta}$, $\mathrm{Sr}, \mathrm{Zr}$ and $\mathrm{Hf}$ anomalies. These data indicate that the initial protolith was mantle-derived peridotite/pyroxenite. Amphibolites show major and trace elements compositions close to those of normal or slightly enriched MORB, though most of them show negative $\mathrm{Nb}$ and $\mathrm{Ta}$ negative anomalies normalized to primitive mantle values (Yonta-Ngouné, 2010).

\section{3. $P-T$ conditions and age of metamorphism}

Phase relationships suggest three main stages of recrystallization. The first stage corresponds to low-grade assemblages synchronous with $S_{1}$ and preserved within grt and ky porphyroblasts. Garnet internal structures and relationships with $\mathrm{S}_{2}$ indicate that their growth is grossly coeval with the development of $S_{2}$ under medium-grade conditions, reaching anatexis in the northwestern part of the map (Fig. 2). The lineation, oriented NNE-SSW, belongs to the second stage, which is also accompanied with the emplacement of quartzofeldspathic veins leading locally to amphibole recrystallization in the talcschist layers.

Thermometric estimates were obtained from mineral compositions determined with a CAMECA SX-50 electron microprobe (SCMEM, Université Henri Poincaré, Nancy). Operating conditions were $20 \mathrm{nA}$ sample current, $15 \mathrm{kV}$ accelerating potential, $20 \mathrm{~s}$ counting times. Calibration was made on a combination of silicates and oxides, and data reduction with the PAP correction procedure. Biotite composition (Henry et al., 2005) and biotite-garnet pairs ([Ferry and Spear, 1978] and [Holdaway, 2000]) give T estimates in the range 595$650{ }^{\circ} \mathrm{C}$ for the micaschists (ig. 3), without significant variation related to their position in the lithostratigraphic pile, and $640-730{ }^{\circ} \mathrm{C}$ for the migmatites. Average $\mathrm{T}$ obtained from the garnet-amphibole thermometer (Graham and Powell, 1984) are consistent with the above estimates though much more variable $\left(570-770{ }^{\circ} \mathrm{C}\right)$. P-T conditions were also estimated using THERMOCALC 3.26 (Powell and Holland, 1988) for the non-migmatitic micaschist ST1 located in the western part of the map and showing grt $+\mathrm{ky}+\mathrm{bt}+\mathrm{ms}+\mathrm{pl}+\mathrm{qtz}$ assemblage. A pseudosection was constructed in the model system MnNCKFMASH (Tinkham et al., 2001) with water in excess ( $\underline{\text { Fig. 3 }})$. Temperatures $\left(620-670{ }^{\circ} \mathrm{C}\right)$ are rather well constrained by the chl(-), st(-)and liq $(+)$ curves. Moreover, using selected mineral compositions and an independent set of five equilibria, the average P-T mode of THERMOCALC 3.26 yields P-T conditions for ST1 shown in Fig. 3. The uncertainty ellipsis 
does not overlap the grt $+\mathrm{ky}+\mathrm{bt}+\mathrm{ms}+\mathrm{pl}+\mathrm{qtz}$ field which lies at lower pressures, a discrepancy assumingly due to the fact that the bulk composition used to construct the pseudosection is not exactly representative of the actual composition (non-homogeneous distribution of plagioclase in the sample). It remains that phase assemblages and thermobarometric data coincide well enough to estimate the conditions of the metamorphic peak at ca. $9.7 \mathrm{kbar}$ and $650{ }^{\circ} \mathrm{C}$ (though slightly higher for the NW migmatites), in agreement with the data obtained from metapelites to the North of the investigated area $\left(609-623^{\circ} \mathrm{C} / 9\right.$ $10 \mathrm{kbar}$ (Stendal et al., 2006)).

We determined the age of the peak conditions by dating monazite from both the kyanite micaschist \#ST1 and a migmatite sample (\#08.21 located in the northwestern corner of the map). This was performed with a Cameca SX50 microprobe (LMTG, Toulouse), operating at $300 \mathrm{nA}$ probe current and $15 \mathrm{kV}$ accelerating voltage. Th is measured on $\mathrm{M} \alpha$ line $\left(\mathrm{ThO}_{2}\right.$ as standard) with $30 \mathrm{~s}$ counting time for peak and background. $\mathrm{U}$ is measured on the $\mathrm{M} \beta$ line (UO2 as standard) with $90 \mathrm{~s}$ on peak and $60 \mathrm{~s}$ on background. $\mathrm{Pb}$ is measured on $\mathrm{M} \beta$ line with $150 \mathrm{~s}$ on peak and $100 \mathrm{~s}$ on background. The three elements are measured with PET crystals, $\mathrm{U}$ and Th being counted on one spectrometer while $\mathrm{Pb}$ is counted on another, more sensible, one. Several difficulties in electron microprobe dating, outlined by (Jercinovic and Williams, $\underline{2005}$ ), are addressed as follows. Peak and background positions have been carefully selected after detailed wavelength dispersive scanning, smoothed by Savitsky-Golay filtering. Using the $\mathrm{M} \beta$ line for $\mathrm{Pb}$ solves many interferences problems, though this line is weaker than the $\mathrm{M} \alpha$ line. Repeated measurements on pure $\mathrm{NdPO}_{4}$ have shown that between the two chosen positions the background curvature can be neglected. Coating problem (carbon coating) has been solved by:

- using moderate voltage;

- doubling the coating thickness;

- continuous on-line monitoring of the absorbed current, which allows the detection of any coating degradation.

The most serious problem lies in the possible interference of the base of the second order Ce $\mathrm{L} \alpha$ line on the $\mathrm{Pb} \mathrm{M} \beta$ line. With $15 \mathrm{kV}$ accelerating voltage this interference is strongly reduced and actually undetectable. The global quality of our procedure is checked daily by measurements on two internal reference samples. Ages are calculated individually for each measurement and the $95 \%$ confidence interval calculated by propagation of counting statistics errors (Ancey et al., 1978) through Monte-Carlo simulation. Global ages are calculated according to (Montel et al., 1996).

Compositions (data available on request) are homogeneous and moderately radioactive, with Th contents ranging from 2.9 to $4.5 \mathrm{wt} \%, \mathrm{U}$ from 0.27 to $0.83 \mathrm{wt} \%$ and $\mathrm{Pb}$ from about 1300 to $2200 \mathrm{ppm}$. This yielded individual ages from 536 to $759 \mathrm{Ma}$. The statistical analysis of the age distributions shows that both populations are homochronological. Sample ST1 gave an age at $622 \pm 43 \mathrm{Ma}(\mathrm{MSWD}=0.59)$ and sample 08.21 an age at $653 \pm 29 \mathrm{Ma}$ $(\mathrm{MSWD}=0.81)$. Because of the moderate actinide content in monazite, the precision remains poor and we cannot determine whether the older age for sample 08.21 is significant, is just a result of statistical dispersion, or indicates some inheritance.

\section{Discussion and conclusions}


These preliminary results allow three points to be discussed:

- geometry of the talcschist occurrences;

- nature and age of metamorphism;

- nature and significance of the protolith of the Pan-African series.

\subsection{Geometry of the talcschist occurrences}

Even though there may be more than one layer of talcschist, most occurrences lie above amphibolites and related micaschists, mostly at the altitude of 400-450 m, suggesting the existence of a main level of talcschist. Moreover, the lower amphibolites and micaschists are crosscut by common hydrothermal quartzofeldspathic veins that are lacking in the upper micaschists. In this respect, the talcschists commonly show recrystallization into amphibole (especially at their base) implying input of $\mathrm{Si}$ and $\mathrm{Ca}$ from beneath. Besides, the talcschists rest directly on the Nyong gneisses to the southwest, suggesting that they might possibly represent a decollement level separating two thrust sheets, a lower one characterized by abundant mafic and ultramafic material, and an upper one essentially metasedimentary (pelites, semipelites). However, additional fieldwork is needed to ascertain this interpretation.

\subsection{Nature and age of metamorphism}

(a) Phase relationships show that the metamorphic peak ( $\left.\sim 650{ }^{\circ} \mathrm{C} / 9.7 \mathrm{kbar}\right)$ corresponds to the second phase of deformation. It is of note that isograds are in normal position, with micaschists passing downwards to migmatites; this suggests that peak conditions post-date nappe emplacement. This is at odds with earlier suggestion of inverted isograds (Nzenti et al., 1988), but is rather consistent with the model of a thermal peak related to extension ([Mvondo et al., 2003] and [Mvondo et al., 2007]). However, retrogression is very limited, with no evidence of significant decompression, a fundamental point, which remains to be addressed. The Pan-African metamorphic imprint is also visible in the Nyong group close to the contact with the Pan-African nappe, especially in amphibolites showing corona textures.

(b) The monazite ages $(622 \pm 43$ and $653 \pm 29 \mathrm{Ma})$ have to be compared to zircon ages of syn-metamorphic intrusions both at Yaoundé (Ngoa-Ekele pyriclasite dated at $620 \pm 10$ and $623 \pm 4 \mathrm{Ma}$ ([Owona, 2008] and [Penaye et al., 1993])) and at Boumnyebel (Mamb metagabbro dated at $618 \pm 7 \mathrm{Ma}$ (Toteu et al., 2006)), and to garnet (616 Ma; $611 \pm 20 \mathrm{Ma}$ ([Stendal et al., 2006] and [Toteu et al., 1994])) and monazite (546-604 Ma (Owona, 2008)) ages obtained on the Yaoundé metasediments. The younger ages are likely to represent cooling ages, as much as they are close to $\mathrm{Rb}-\mathrm{Sr}$ mica-whole rock isochron ages (554-599 Ma (Owona, 2008)), whereas the oldest ones probably suggest some inheritance. This interpretation is corroborated by the presence of core-rim texture in some monazite grains. We consider that the best estimate for the peak metamorphic conditions is likely to be around $620 \mathrm{Ma}$.

\subsection{Nature and significance of the protolith of the Pan-African series}

The rocks in the Boumnyebel area correspond to the westward extension of the Yaoundé metasediments, and are interpreted as products of erosion of magmatic arcs and crustal rocks (Stendal et al., 2006). The abundance in the lower part of the Pan-African unit of both 
amphibolites with MORB-type chemistry (similar amphibolites occur also to the south of Yaoundé (Owona, 2008)) and talcschists, likely to represent former mantle-derived peridotites/pyroxenites, raises once again the question of the geodynamic context of the southern part of the CAFB. Two main interpretations have been proposed:

- passive margin (no oceanic lithosphere remnants ([Mvondo et al., 2003] and [Mvondo et al., 2007]) or remnants of a rift stage ([Nzenti et al., 1988] and [Vicat et al., 1997]));

- active margin (magmatic arc (Stendal et al., 2006) or dismembered ophiolite (Nkoumbou et al., 2006a).

Our data support the second interpretation and testify to the existence of an active margin (possibly ancient ophiolites) to the north of the Congo craton during the Early Neoproterozoic.

In conclusion, the presence of mafic and ultramafic rocks in the lower part of the series reinforces the likelihood of a suture in the southernmost part of the CAFB, resulting from a collision between the Adamaoua-Yadé block to the north and the Congo craton to the south. Conversely, we have to acknowledge that the tectonic model of ([Mvondo et al., 2003] and [Mvondo et al., 2007]) appears as the most suitable in the present state of knowledge, and we agree that two main stages (i.e. the two deformation phases reported in the previous papers) prevailed during the Pan-African orogenic phase:

- collision with nappe emplacement onto the Congo craton followed by;

- high-T metamorphic conditions associated with extension as suggested in the Yaoundé area (at ca. $620 \mathrm{Ma}$ ).

Ongoing studies, including extensive geological mapping, will help us to characterize more tightly the nature and significance of these mafic and ultramafic rocks on the geodynamic context. 


\section{References}

Abdelsalam et al., 2002 M.G. Abdelsalam, J.P. Liégeois and R.J. Stern, The Saharan metacraton, J. Afr. Earth Sci. 34 (2002), pp. 119-136.

Ancey et al., 1978 M. Ancey, F. Bastenaire and R. Tixier, Application des méthodes statistiques en microanalyse. In: F. Maurice, L. Meny and R. Tixier, Editors, Microanalyse, microscopie électronique à balayage, Les Éditions du Physicien, Orsay, France (1978), pp. 323-347.

Ball et al., 1984 E. Ball, J.P. Bard and D. Soba, Tectonique tangentielle dans la catazone panafricaine du Cameroun, les gneiss de Yaoundé, J. Afr. Earth Sci. 2 (1984), pp. 91-95.

Champetier de Ribes and Aubague, 1956 G. Champetier de Ribes and M. Aubague, Carte géologique de reconnaissance à l'échelle du 1/500 000, Feuille Yaoundé-Est, avec notice explicative, Direction des Mines et de la Géologie (1956), p. 35p.

Ferry and Spear, 1978 J.M. Ferry and F.S. Spear, Experimental calibration of the partitioning of Fe and Mg between biotite and garnet, Contrib. Mineral. Petrol 66 (1978), pp. 113-117.

Feybesse et al., 1998 J.L. Feybesse, V. Johan, C. Triboulet, C. Guerrot, F. Mayaga-Mikolo, V. Bouchot and J. Eko N'dong, The West Central African belt: A model of 2.5-2.0 Ga accretion and two-phase orogenic evolution, Precamb. Res. 87 (1998), pp. 161-216.

Graham and Powell, 1984 C.M. Graham and R. Powell, A garnet-hornblende geothermometer: Calibration, testing and application to Pelona Schist, Southern California, $J$. Metam. Geol. 2 (1984), pp. 13-21.

Henry et al., 2005 D.J. Henry, C.V. Guidotti and J.A. Thomson, The Ti-saturation surface for low-to-medium pressure metapelitic biotites: Implications for geothermometry and Tisubstitution mechanisms, Amer. Mineral. 90 (2005), pp. 316-328.

Holdaway, 2000 M.J. Holdaway, Application of new experimental and garnet Margules data to the garnet-biotite geothermometer, Amer. Mineral. 85 (2000), pp. 881-892.

Jercinovic and Williams, 2005 M.J. Jercinovic and M.L. Williams, Analytical perils (and progress) in electron microprobe trace element analysis applied to geochronology:

Background acquisition, interferences, and beam irradiation effects, Amer. Mineral. 90 (2005), pp. 526-546.

$\underline{\text { Kretz, } 1983}$ R. Kretz, Symbols for rock-forming minerals, Amer. Mineral. 68 (1983), pp. 277-279.

Lerouge et al., 2006 C. Lerouge, A. Cocherie, S.F. Toteu, J. Penaye, J.P. Milési, R. Tchameni, E.N. Nsifa, C.M. Fanning and E. Deloule, Shrimp U-Pb zircon age evidence for Paleoproterozoic sedimentation and 2.05 Ga syntectonic plutonism in the Nyong Group, southwestern Cameroon: Consequences for the Eburnean-Transamazonian belt of NE Brazil and central Africa, J. Afr. Earth Sci. 44 (2006), pp. 413-427. 
Montel et al., 1996 J.-M. Montel, S. Foret, M. Veschambre, C. Nicollet and A. Provost, Electron microprobe dating of monazite, Chem. Geol. 131 (1996), pp. 37-53.

Mvondo et al., 2003 H. Mvondo, S.W.J. den Brok and J. Mvondo Ondoa, Evidence of symmetric extension and exhumation of the Yaoundé nappe (Pan-African fold belt, Cameroon), J. Afr. Earth Sci. 36 (2003), pp. 215-231.

Mvondo et al., 2007 H. Mvondo, S. Owona, J. Mvondo Ondoa and J. Essono, Tectonic evolution of the Yaounde segment of the Neoproterozoic Central African Orogenic Belt in southern Cameroon, Can. J. Earth Sci. 44 (2007), pp. 433-444.

Nédélec et al., 1993 A. Nédélec, A. Minyem and P. Barbey, HP-HT anatexis of Archaean grey gneisses: The Eseka migmatites (Cameroon), Precamb. Res. 62 (1993), pp. 191-205.

Ngako et al., 1991 V. Ngako, P. Jegouzo and J.P. Nzenti, Le Cisaillement Centre

Camerounais. Rôle structural et géodynamique dans l'orogenèse panafricaine, C. R. Acad. Sci.

Paris, Sér. II 313 (1991), pp. 457-463.

Ngako et al., 2008 V. Ngako, P. Affaton and E. Njongfang, Pan-African tectonics in northwestern Cameroon: Implication for the history of western Gondwana, Gondwana Res. 14 (2008), pp. 509-522.

Nkoumbou et al., 2006a C. Nkoumbou, C. Yonta-Ngouné, F. Villiéras, D. Njopwouo, J. Yvon, G.E. Ekodeck and F. Tchoua, Découverte de roches à affinité ophiolitique dans la chaîne panafricaine au Cameroun : les talcschistes de Ngoung, Lamal Pougué et Bibodi Lamal, $C$. $R$. Geoscience 338 (2006), pp. 1167-1175.

Nkoumbou et al., 2006b C. Nkoumbou, D. Njopwouo, F. Villiéras, A. Njoya, C. Yonta Ngoune, L. Ngo Ndjock, F.M. Tchoua and J. Yvon, Talc indices from Boumnyebel (central Cameroon), physico-chemical characteristics and geochemistry, J. Afr. Earth Sci. 45 (2006), pp. 61-73.

Nzenti et al., 1988 J.P. Nzenti, P. Barbey, J. Macaudière and D. Soba, Origin and evolution of the Late Precambrian high-grade Yaoundé gneisses (Cameroon), Precamb. Res 38 (1988), pp. 91-109.

Oliveira et al., 2006 E.P. Oliveira, S.F. Toteu, M.N.C. Araújo, M.J. Carvalho, R.S. Nacimento, J.F. Buen, N. McNaughton and G. Basilici, Geologic correlation between the Neoproterozoic Sergipano belt (NE Brazil) and the Yaoundé schist belt (Cameroon, Africa), J. Afr. Earth Sci. 44 (2006), pp. 470-478.

Owona, 2008 Owona, S., 2008. Archaean, Eburnean and Pan-African junction in the South of Yaounde (Cameroon). Unpubl. thesis Douala, 213 p.

Penaye et al., 2006 J. Penaye, A. Kröner, S.F. Toteu, W.R. Van Schmus and J.C. Doumnang, Evolution of the Mayo Kebbi region as revealed by zircon dating: An early (ca. $740 \mathrm{Ma}$ ) PanAfrican magmatic arc in southwestern Chad, J. Afr. Earth Sci. 44 (2006), pp. 530-542.

Penaye et al., 1993 J. Penaye, S.F. Toteu, W.R. Van Schmus and J.P. Nzenti, U-Pb and Sm$\mathrm{Nd}$ preliminary geochronologic data on the Yaoundé series Cameroon: Signification of the 
granulitic rocks in the «Centrafrican » belt, C. R. Acad. Sci. Paris Sér. II 317 (1993), pp. 789-794.

Pouclet et al., 2006 A. Pouclet, M. Vidal, J.C. Doumnang, J.P. Vicat and R. Tchameni, Neoproterozoic crustal evolution in Southern Chad: Pan-African ocean basin closing, arc accretion and late- to post-orogenic granitic intrusion, J. Afr. Earth Sci. 44 (2006), pp. 543560.

Powell and Holland, 1988 R. Powell and T.J.B. Holland, An internally consistent thermodynamic dataset with uncertainties and correlations: 3. Application methods, worked examples and a computer program, J. metam. Geol. 6 (1988), pp. 173-204.

Powell and Holland, 1994 R. Powell and T.J.B. Holland, Optimal geothermometry and geobarometry, Amer. Mineral. 79 (1994), pp. 120-133.

Stendal et al., 2006 H. Stendal, S.F. Toteu, R. Frei, J. Penaye, U.O. Njel, J. Bassahak, J. Nni, B. Kankeu, V. Ngako and J.V. Hell, Derivation of detrital rutile in the Yaounde region from the Neoproterozoic Pan-African belt in southern Cameroon (Central Africa), J. Afr. Earth Sci. 44 (2006), pp. 443-458.

Tchakounté et al., 2007 J.N. Tchakounté, S.F. Toteu, W.R. Van Schmus, J. Penaye, E. Deloule, J. Mvondo Ondoua, M.B. Houketchang, A.A. Ganwa and W.M. White, Evidence of ca. 1. 6-Ga detrital zircon in the Bafia Group (Cameroon): Implication for the chronostratigraphy of the Pan-African Belt north of the Congo craton, C. R. Geoscience 339 (2007), pp. 132-142.

Tinkham et al., 2001 D.K. Tinkham, C.A. Zuluaga and H.H. Stowell, Metapelite phase equilibria modelling in MnNCKFMASH: The effect of variable $\mathrm{Al}_{2} \mathrm{O}_{3}$ and $\mathrm{MgO} /(\mathrm{MgO}+\mathrm{FeO})$ on mineral stability, Geol. Mater. Res. 3 (2001), pp. 1-42.

Toteu et al., 2004 S.F. Toteu, J. Penaye and Y.H. Poudjom Djomani, Geodynamic evolution of the Pan-African belt in Central Africa with special reference to Cameroon, Can. J. Earth Sci. 41 (2004), pp. 73-85.

Toteu et al., 2001 S.F. Toteu, W.R. Van Schmus, J. Penaye and A. Michard, New U-Pb and $\mathrm{Sm}-\mathrm{Nd}$ data from north-central Cameroon and its bearing on the pre-Pan-African history of central Africa, Precambrian Res. 108 (2001), pp. 45-73.

Toteu et al., 1994 S.F. Toteu, W.R. Van Schmus, J. Penaye and J.B. Nyobé, U-Pb and Sm-Nd evidence for Eburnean and Pan-African high-grade metamorphism in cratonic rocks of southern Cameroon, Precamb. Res. 67 (1994), pp. 321-347.

Toteu et al., 2006 S.F. Toteu, R. Yongue Fouateu, J. Penaye, J. Tchakounté, A.C. Seme Mouangue, W.R. Van Schmus, E. Deloule and H. Stendal, U-Pb dating of plutonic rocks involved in the nappe tectonic in southern Cameroon: Consequence for the Pan-African orogenic evolution of the Central African fold belt, J. Afr. Earth Sci. 44 (2006), pp. 479-493.

Vicat et al., 1997 J.P. Vicat, A. Pouclet, C. Nkoumbou and A.C. Seme Mouangue, Le volcanisme fissural néoprotérozoïque des séries du Dja inférieur, de Yokadouma (Cameroun) 
et de Nola (RCA) : signification géotectonique, C. R. Acad. Sci. Paris, Ser. IIa 325 (1997), pp. 671-677.

Yonta-Ngouné, 2010 Yonta-Ngouné, C., 2010. Contexte géologique de la région de Boumnyebel (chaîne panafricaine d'Afrique Centrale, Cameroun). Unpublished thesis, Univ. Yaounde, 214 p. 
Figures and Tables

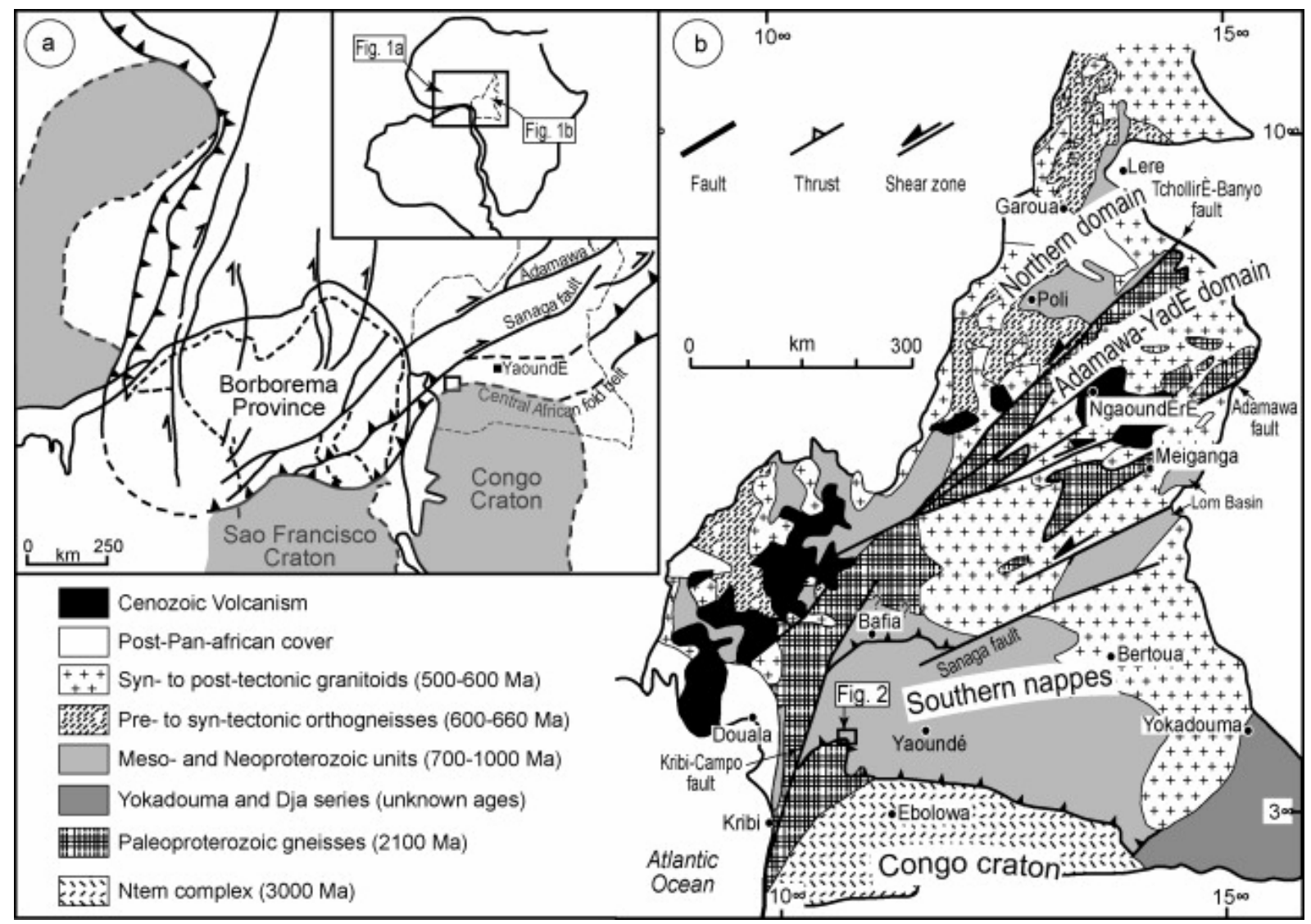

Fig. 1.

The Pan-African Belt of Central Africa: (a) continent scale geodynamic reconstruction (Oliveira et al., 2006); (b) main subdivisions in Cameroun redrawn from ([Ngako et al., 2008], [Tchakounté et al., 2007] and [Toteu et al., 2001]).

La chaîne panafricaine d'Afrique centrale : (a) reconstitution géodynamique à l'échelle continentale (Oliveira et al., 2006) ; (b) principales subdivisions au Cameroun d'après ([Ngako et al., 2008], [Tchakounté et al., 2007] and [Toteu et al., 2001]). 


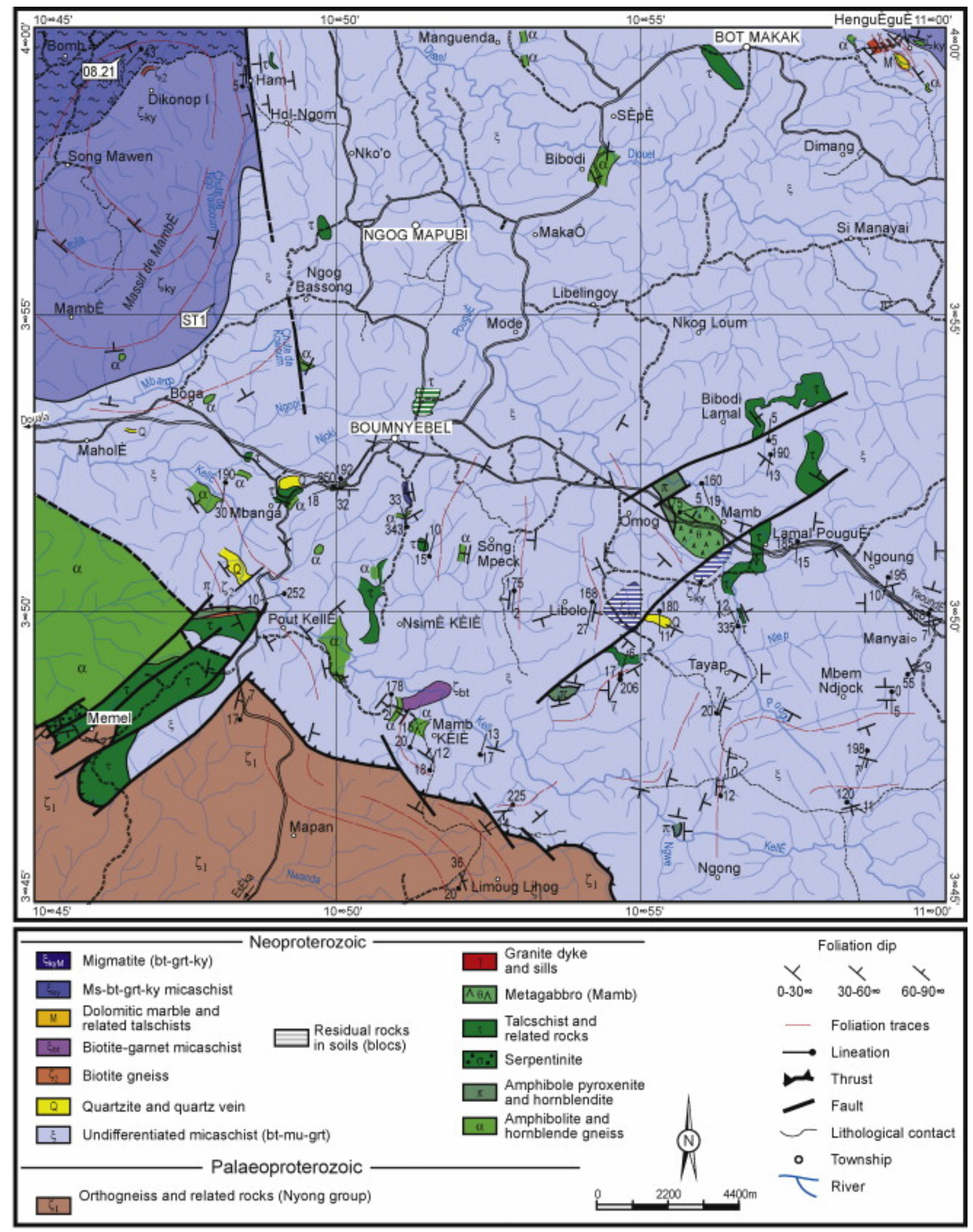

Fig. 2.

Geological map of the Boumnyebel area redrawn from author's field data.

Esquisse géologique de la région de Boumnyebel redessinée à partir des levers des auteurs. 


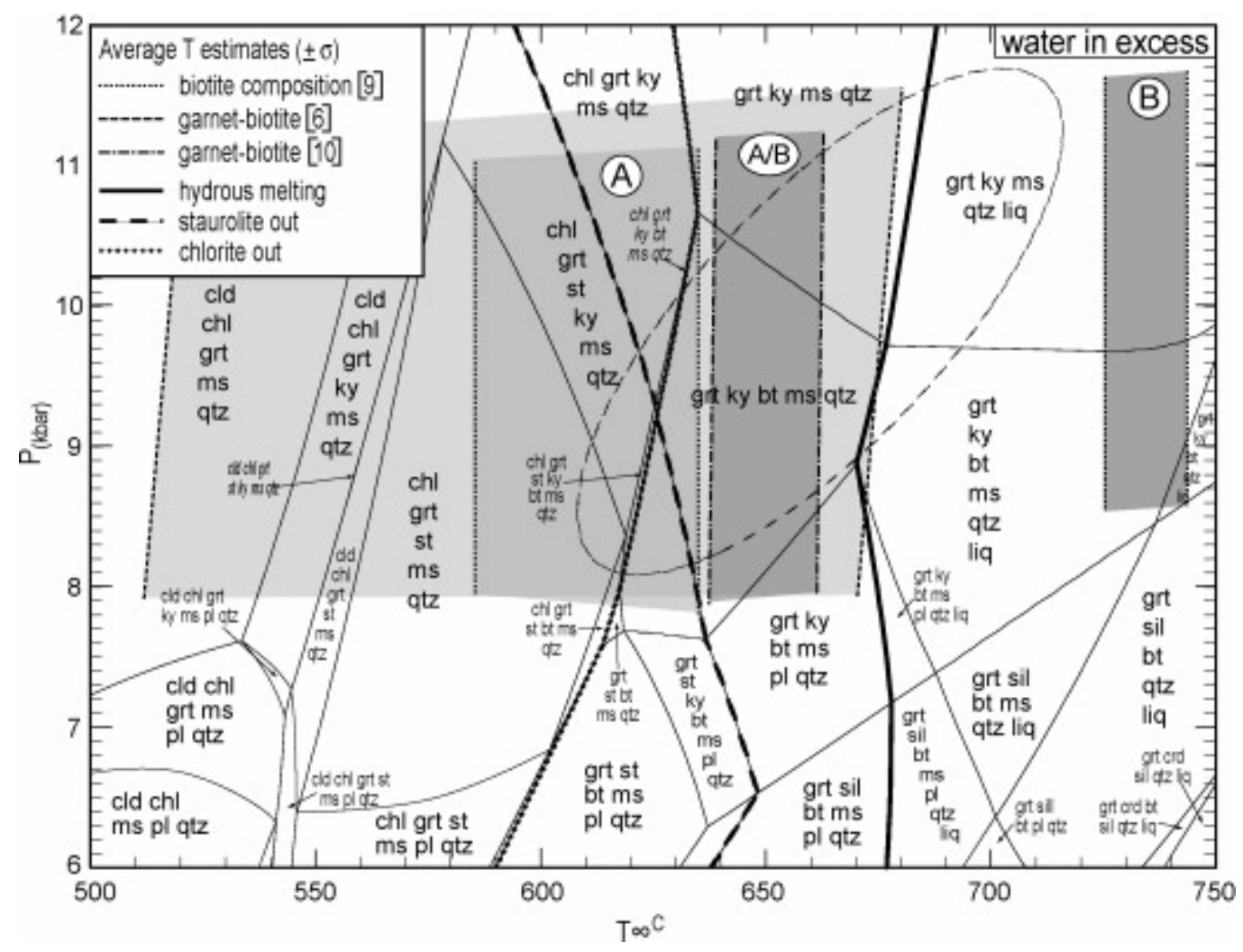

Fig. 3.

P-T pseudosection and estimates for kyanite micaschist ST1 (dashed ellipsis $=2 \sigma$ error) using THERMOCALC version 3.26 ([Powell and Holland, 1988] and [Powell and Holland, 1994]). Also shown are $\mathrm{T}$ ranges estimated for micaschists (A) and migmatites (B) from biotite thermometry.

Pseudosection et estimation des conditions P-T pour un micaschiste à disthène obtenu avec THERMOCALC version 3.26 ([Powell and Holland, 1988] and [Powell and Holland, 1994]). Sont également indiquées les gammes de $\mathrm{T}$ obtenues à partir de la biotite des micaschistes (A) et des migmatites (B). 